\title{
Correction to: Transcriptome signature of miRNA-26b KO mouse model suggests novel targets
}

Emiel P. C. van der Vorst ${ }^{1,2,3,4^{*}+}$, Mario A. A. Pepe ${ }^{5 \dagger}$, Linsey J. F. Peters ${ }^{1,2,3,4}$, Markus Haberbosch ${ }^{1}$, Yvonne Jansen ${ }^{1}$, Ronald Naumann ${ }^{6}$, Georgios T. Stathopoulos ${ }^{5}$, Christian Weber ${ }^{1,2,7,8+}$ and Kiril Bidzhekov ${ }^{1 *+}$

\section{Correction to: BMC Genom Data 22, 23 (2021) https://doi.org/10.1186/s12863-021-00976-1}

Following publication of the original article [1], the authors identified an error in the author name of Ronald Naumann.

The incorrect author name is: Ronald Nauman

The correct author name is: Ronald Naumann

The author group has been updated above and the original article [1] has been corrected.

\section{Author details}

${ }^{1}$ Institute for Cardiovascular Prevention (IPEK), Ludwig-Maximilians-Universität (LMU) München, Munich, Germany. ${ }^{2}$ DZHK (German Centre for Cardiovascular Research), Partner site Munich Heart Alliance, Munich, Germany. ${ }^{3}$ Interdisciplinary Center for Clinical Research (IZKF), Institute for Molecular Cardiovascular Research (IMCAR), RWTH Aachen University, Aachen, Germany. ${ }^{4}$ Department of Pathology, Cardiovascular Research Institute Maastricht (CARIM), Maastricht University, Maastricht, the Netherlands. ${ }^{5} \mathrm{Helm} h o l t z$ Center Munich, Munich, Germany. ${ }^{6} \mathrm{MPI}$ of Molecular Cell Biology and Genetics, Dresden, Germany. ${ }^{7}$ Department of Biochemistry, Cardiovascular Research Institute Maastricht (CARIM), Maastricht University, Maastricht, The Netherlands. ${ }^{8}$ Munich Cluster for Systems Neurology (SyNergy), Munich, Germany.

Published online: 20 September 2021

\section{Reference}

1. van der Vorst, et al. Transcriptome signature of miRNA-26b KO mouse model suggests novel targets. BMC Genom Data. 2021;22:23. https://doi. org/10.1186/s12863-021-00976-1.

The original article can be found online at https://doi.org/10.1186/s12863021-00976-1.

* Correspondence: Emiel.van_der_Vorst@med.uni-muenchen.de;

Kiril.Bidzhekov@med.uni-muenchen.de

${ }^{\dagger}$ Emiel P. C. van der Vorst, Mario A. A. Pepe, Christian Weber and Kiril Bidzhekov contributed equally to this work.

'Institute for Cardiovascular Prevention (IPEK), Ludwig-Maximilians-Universität (LMU) München, Munich, Germany

Full list of author information is available at the end of the article

C The Author(s). 2021 Open Access This article is licensed under a Creative Commons Attribution 4.0 International License, which permits use, sharing, adaptation, distribution and reproduction in any medium or format, as long as you give appropriate credit to the original author(s) and the source, provide a link to the Creative Commons licence, and indicate if changes were made. The images or other third party material in this article are included in the article's Creative Commons licence, unless indicated otherwise in a credit line to the material. If material is not included in the article's Creative Commons licence and your intended use is not permitted by statutory regulation or exceeds the permitted use, you will need to obtain permission directly from the copyright holder. To view a copy of this licence, visit http://creativecommons.org/licenses/by/4.0/. The Creative Commons Public Domain Dedication waiver (http://creativecommons.org/publicdomain/zero/1.0/) applies to the data made available in this article, unless otherwise stated in a credit line to the data. 